\title{
Pelatihan Kader Kesehatan untuk Penemuan Penderita Suspek Tuberkulosis
}

\author{
Health Cadre Training for Suspected Tuberculosis Case Detection
}

\author{
Chatarina Umbul Wahyuni, Kurnia Dwi Artanti
}

Departemen Epidemiologi Fakultas Kesehatan Masyarakat Universitas Airlangga

\begin{abstract}
Abstrak
Di Indonesia, kasus tuberkulosis (TB) yang dilaporkan pada tahun 2011 terdeteksi lebih dari 70\% dan cenderung terus meningkat. Di Kota Surabaya, cakupan penemuan penderita adalah sekitar $49,52 \%$ dengan jumlah suspek TB sebanyak 4.402 orang hingga tahun 2011. Keterlibatan masyarakat dalam penanggulangan TB tersebut sesuai dengan Kerangka Kerja Strategi Penanggulangan TB 2006 - 2010. Masyarakat berpeluang untuk berperan dalam penanggulangan TB, sumber daya di masyarakat dimanfaatkan untuk meningkatkan derajat kesehatan dan mengubah perilaku masyarakat. Penelitian ini bertujuan mengetahui pengaruh pelatihan terhadap pengetahuan kader kesehatan dalam penemuan suspek TB. Penelitian kuantitatif ini menggunakan rancangan studi kuasi eksperimental kelompok kontrol non-ekuivalen. Perlakuan pelatihan program pengendalian berupa penemuan suspek TB. Populasi penelitian adalah ibu rumah tangga di wilayah kerja Puskesmas Mojo di Kota Surabaya dengan jumlah sampel 90 ibu rumah tangga berumur rata-rata 48 tahun, tingkat pendidikan terbanyak adalah tamat SMA (58,9\%). Setelah pelatihan, pengetahuan kader tentang penemuan suspek TB meningkat dari 67 (74,4\%) menjadi 89 (98,9\%). Perlu implementasi untuk melihat kemampuan kader menerapkan pengetahuan yang diperoleh dalam menemukan suspek penderita TB dengan pendampingan dan monitoring kader.

Kata kunci: Ibu rumah tangga, kader kesehatan, pelatihan, penemuan suspek TB, pengetahuan
\end{abstract}

\section{Abstract}

Progress reports current situation of tuberculosis (TB) in Indonesia in 2011 showed Case Detection Rate (CDR) of over $70 \%$ and showed an increase from year to year. While the city of Surabaya figures coverage discovery Patients up to 2011 amounted to $49.52 \%$ with the number of 4,402 people suspected. Community involvement in TB control in accordance with the Tuberculosis Control Strategy Framework 2006 - 2010. The opportunities as well as public opportunities to participate in TB control to make the re- sources available in the community should be utilized to improve health status and change people's behavior as a factor influencing health status. This study aimed to determine the effect of training on the knowledge of health cadres in the discovery of suspected tuberculosisThis study uses quantitative methods to the design of a Quasi Nonequivalent Experimental Control Group Design. Treatment will be given in the form of training on tuberculosis control program in the discovery suspected tuberculosis. The population in this study was a housewife in Puskesmas Mojo working in the city of Surabaya. Large sample taken as many as 90 respondents. Characteristics housewife with average age 48 years, female gender, and education all most $31.1 \%$. Improvement occurred knowledge of 67 (74.4\%) health workers who have good knowledge before training to 89 (98.9\%). Based on the results of this study concluded increased knowledge of health workers after training in the discovery of suspected tuebrkulosis. Further implementation is needed to see the ability of the implementing cadres who have acquired knowledge in finding patients with suspected tuberculosis in the surrounding environment. In its application may be made to the guidance and monitoring of health cadres in the process of discovery with suspected tuberculosis.

Keywords: Housewife, health cadres, training, the detection of suspected tuberculosis, knowledge

\section{Pendahuluan}

Tuberkulosis (TB) adalah penyakit menular langsung yang disebabkan oleh Mycobacterium tuberculosis yang sebagian besar menyerang paru, tetapi dapat juga menyerang organ tubuh yang lain. Diperkirakan sekitar sepertiga penduduk dunia telah terinfeksi oleh Mycobacterium

Alamat Korespondensi: Chatarina Umbul Wahyuni, Departemen Epidemiologi FKM Universitas Airlangga, Kampus C Unair, Jl. Mulyorejo Surabaya, Hp. 081803298525,e-mail: chatrin03@yahoo.com 
tuberculosis, sekitar 95\% kasus TB dan 98\% kematian akibat TB di dunia, terjadi di berbagai negara berkembang. Kematian wanita akibat TB lebih banyak daripada kematian akibat kehamilan, persalinan, dan nifas, dengan perkiraan peningkatan jumlah pasien sekitar 2,8 hingga 5,6 juta jiwa setiap tahun, dan sekitar 1,1 hingga 2,2 juta kematian akibat TB. ${ }^{1}$ Di Indonesia, sampai kini tercatat sekitar seperempat juta kejadian kasus dan 140.000 kematian akibat TB setiap tahun. ${ }^{2}$ Laporan terkini menunjukkan Case Detection Rate (CDR) lebih dari 70\% dan memperlihatkan tren yang meningkat dari tahun ke tahun. Kota Surabaya menargetkan CDR $>70 \%$, secara umum, dari tahun ke tahun, angka penjaringan suspek memperlihatkan peningkatan yang signifikan. ${ }^{3}$ Sampai dengan tahun 2011. Di Surabaya ibu kota provinsi Jawa Timur, angka cakupan penemuan penderita dilaporkan sekitar 49,52\% dengan jumlah suspek 4.402 orang. Dengan demikian, terjadi peningkatan $36,65 \%$ dengan jumlah suspek 3.150 kasus dibandingkan tahun sebelumnya. ${ }^{4}$

Departemen kesehatan mempunyai visi terbentuk masyarakat mandiri dalam hidup sehat, TB tidak menjadi masalah kesehatan masyarakat dan dikembangkan melalui program penanggulangan $\mathrm{TB}$, dengan strategi melibatkan masyarakat. Namun, penemuan suspek dan kasus TB melalui fasilitas kesehatan masih belum maksimal, sehingga perlu dikembangkan sistem surveilans penemuan suspek TB berbasis masyarakat yang bertujuan meningkatkan peran serta anggota masyarakat dalam penemuan suspek TB yang ada di wilayahnya. Hal tersebut sesuai dengan tujuan pemberdayaan, membantu klien memperoleh kemampuan mengambil keputusan dan menentukan tindakan yang berhubungaan dengan diri mereka sendiri. Pemberdayaan didefinisikan sebagai to give ability to or enable, berupaya memberi kemampuan dan keberdayaan. Pemberdayaan adalah suatu proses aktif, yang menuntut peran aktif masyarakat yang diberdayakan dalam berbagai kegiatan. Dengan demikian, masyarakat mempunyai tingkat kemandirian yang tinggi dengan mendapatkan pengalaman aktual, yang sangat berguna untuk mengembangkan program sejenis pada masa yang akan datang. Agar masyarakat berperan dalam kegiatan surveilans berbasis masyarakat, peran petugas kesehatan dalam memfasilitasi untuk meningkatkan kemampuan dan keberdayaan masyarakat sangat penting. Hal tersebut dilakukan melalui upaya promosi kesehatan yang membantu individu dan masyarakat meningkatkan kemampuan dan keterampilan mengendalikan berbagai faktor yang berpengaruh pada kesehatan untuk meningkatkan derajat kesehatan. Upaya promosi kesehatan dilakukan melalui pendekatan pendidikan, prevensi dan proteksi pada tingkat individu yang berhubungan dengan surveilans TB berbasis masyarakat. ${ }^{5}$

Kegiatan promosi kesehatan adalah pengetahuan ten- tang TB meliputi pengertian, gejala, pengobatan sampai pada pencegahan TB sehingga terjadi perbaikan sikap dan perilaku masyarakat terhadap TB. Pada tahun 2004, sekitar 96\% keluarga merawat anggota keluarga yang menderita TB dan hanya sekitar 13\% yang menyembunyikan anggota keluarga tersebut, tetapi hanya sekitar $76 \%$ keluarga yang pernah mendengar tentang TB, seki$\operatorname{tar} 26 \%$ dapat menyebutkan dua tanda dan gejala utama, sekitar 51\% memahami cara penularan, dan sekitar 19\% memahami bahwa program pengelolaan TB menyediakan obat TB gratis. Di Kabupaten Gowa, Sulawesi Selatan, ternyata guru SD $(28,7 \%)$ mempunyai pengetahuan lebih baik daripada mantan penderita TB $(20,7 \%){ }^{6}$ Peluang berperan dalam penanggulangan $\mathrm{TB}$, membuat sumber daya di masyarakat perlu dimanfaatkan dalam meningkatkan derajat kesehatan dan mengubah perilaku masyarakat. Keterlibatan masyarakat dalam penanggulangan TB sesuai dengan Kerangka Kerja Strategi Penanggulangan TB 2006 - 2010, meliputi ekspansi program pengendalian TB untuk memepertahankan cakupan dan mutu strategi DOTS. Strategi yang kedua, melibatkan masyarakat atau mantan penderita sehingga permasalahan akses, pembiayaan pengobatan penderita $\mathrm{TB}$ dapat dikurang dan terjadi optimalisasi infrastruktur dan sumber daya manusia yang tersedia.

Sebagai unsur dasar pemberdayaan, partisipasi harus ditumbuhkan melalui terapi pendidikan yang merupakan suatu rancangan proses pengembangan rasa percaya diri dan pada akhirnya tumbuh keyakinan bahwa yang dapat menolong adalah diri sendiri. Dalam terapi pendidikan, berbagai upaya pelatihan yang membuat anggota masyarakat saling bekerja sama dilakukan untuk memecahkan berbagai masalah mereka, serta merasakan manfaat bekerja sama dan memetik berbagai nilai dari kerjasama tersebut. Keberhasilan surveilans TB berbasis masyarakat dapat dilihat dari banyak suspek yang ditemukan masyarakat. Penemuan suspek oleh masyarakat dipengaruhi oleh pengetahuan mereka tentang $\mathrm{TB}$, semakin baik pengetahuan, semakin mudah masyarakat mengenali kasus melalui gejala yang ada. Penyebab dari penyakit TB, cara penularan penyakit TB sehingga nantinya dapat melakukan pencegahan, dan apakah masyarakat mau menerima penderita TB di lingkungannya? Apakah ada stigma di masyarakat tentang TB? Stigma akan mempersulit masyarakat menemukan TB karena masyarakat menghindari penderita, bahkan keluarga mungkin menghindarkan penderita dari lingkungan. Perilaku masyarakat dalam pencegahan dan penularan $\mathrm{TB}$, terlihat pada perhatian yang rendah terhadap higiene dan lingkungan yang berhubungan sangat erat dengan penularan TB. Perilaku masyarakat mencari pelayanan pengobatan TB berpengaruh terhadap penemuan tersangka TB yang rendah. Motivasi masyarakat pada tersangka TB mempengaruhi kesediaan tersangka TB untuk 
datang ke puskesmas memeriksakan diri dan mendapatkan pengobatan gratis.

Kesempatan masyarakat berperan serta dalam penanggulangan TB memberi peluang sumber daya dimasyarakat untuk dimanfaatkan pada upaya peningkatan derajat kesehatan serta pengubahan perilaku masyarakat yang berpengaruh terhadap derajat kesehatan. Penelitian ini bertujuan mengetahui pengaruh pelatihan terhadap pengetahuan kader kesehatan dalam penemuan suspek TB.

\section{Metode}

Penelitian ini menggunakan desain studi kuasi eksperimental berupa nonequivalent control group design. Sampel penelitian adalah ibu rumah tangga di wilayah Puskesmas Mojo dan jumlah sampel 90 orang yang diambil secara simple random sampling. Penelitian dilakukan dalam kurun waktu 3 bulan. Perlakuan yang diberikan berupa pelatihan tentang penemuan suspek TB. Kriteria inklusi adalah kader kesehatan, ibu rumah tangga, dan bersedia terlibat dalam penelitian. Sedangkan, kriteria eksklusi meliputi dalam kondisi sakit yang dapat mengganggu aktivitas dalam menjalankan tugasnya sebagai kader kesehatan. Instrumen pengumpulan data yang dilakukan adalah dengan menggunakan kuesioner pretest dan posttest. Pelaksanaan penelitian telah dilakukan uji etik oleh komite etik Fakultas Kesehatan Masyarakat Universitas Airlangga. Inform consent dilakukan setelah responden mendapatkan penjelasan mengenai tujuan penelitian. Analisis dijelaskan secara deskriptif dengan menggunakan uji univariat.

\section{Hasil}

Kader terbanyak adalah kelompok usia 51-60 tahun dan yang terendah adalah pada kelompok 31 - 40 tahun. Kader pada kelompok usia tua lebih aktif karena tersedia banyak waktu pada pagi hari serta ada komitmen menyehatkan warga di lingkungan mereka. Mayoritas pendidikan adalah tamatan SMA sebanyak 53 orang. Selanjutnya, diikuti oleh tamatan SMP sebnayak 22 orang dan tamatan SD sebanyak 12 orang dengan total jumlah kader sebanyak 90 orang(Tabel 1).

Pengetahuan merupakan faktor yang sangat penting membentuk tindakan seseorang, perilaku yang didasari pengetahuan akan lebih langgeng daripada yang tidak. Pengetahuan memengaruhi kader ditemukan. Pengetahuan kader tentang TB Paru yang tertinggi adalah dengan nilai yang tergolong baik $74,4 \%$ dan terendah dengan nilai kurang $25,6 \%$. Terdapat perbedaan bermakna antara pengetahuan tentang TB pada pretest dibandingkan dengan posttest (nilai $\mathrm{p}<0,05$ ) (Tabel 2).

Sebelum intervensi, sebagian besar kader menyatakan penyebab tuberkulosis adalah kuman, cukup banyak yang mengatakan penyebab penyakit $\mathrm{TB}$ adalah virus, dan masih ada yang menjawab penyebab penyakit $\mathrm{TB}$
Tabel 1. Karakteristik Kader

\begin{tabular}{llll}
\hline Variabel & Kategori & $\mathbf{n}$ & $\%$ \\
\hline Usia & $31-40$ tahun & 3 & 3,3 \\
& $41-50$ tahun & 14 & 15,6 \\
& $51-60$ tahun & 36 & 40 \\
\multirow{4}{*}{ Pendidikan } & $>60$ tahun & 28 & 31,1 \\
& Tamat SD & 12 & 13,3 \\
& Tamat SMP & 22 & 24,4 \\
& Tamat SMA & 53 & 58,9 \\
Total & Tamat PT & 3 & 3,3 \\
\hline
\end{tabular}

Tabel 2. Distribusi Pengetahuan Kader Tentang TB Sebelum dan Setelah Pelatihan

\begin{tabular}{lllllll}
\hline & \multicolumn{7}{c}{ Pengetahuan } \\
\cline { 2 - 7 } Jenis Tes & \multicolumn{2}{c}{ Baik } & \multicolumn{2}{c}{ Kurang } & \multicolumn{2}{c}{ Total } \\
\cline { 2 - 7 } & $\mathbf{n}$ & $\%$ & $\mathbf{n}$ & $\%$ & $\mathbf{n}$ & $\%$ \\
\hline Pretest & 67 & 74,4 & 23 & 25,6 & 90 & 100 \\
Posttest & 89 & 98,9 & 1 & 1,1 & 90 & 100 \\
\hline Total & $\mathbf{1 5 6}$ & & $\mathbf{2 4}$ & & $\mathbf{1 8 0}$ \\
\hline
\end{tabular}

adalah angin malam dan merokok (Tabel 3).

Sebelum pelatihan, sebagian besar kader mengatakan gejala utama TB paru adalah batuk lebih dari 2 minggu dan setelah pelatihan meningkat, tetapi belum seluruhnya. Sebelum pelatihan, sebagian besar kader mengatakan pada penyakit TB paru dilakukan pemeriksaan dahak dan setelah pelatihan meningkat $21 \%$, tetapi belum keseluruhan (Tabel 4).

Sebelum pelatihan, sebagian besar kader dapat menjawab lama pengobatan TB 6 bulan $(87,8 \%)$ dan meningkat tajam setelah pelatihan $(94,4 \%)$. Pengobatan TB selama 6 bulan bertujuan menyembuhkan penderita TB dengan memutuskan rantai penularan. Kegagalan pengobatan dapat menyebabkan kekebalan terhadap obat TB. Sebelum pelatihan, sebagian besar kader $(57,8 \%)$ menyatakan pengobatan TB bertujuan memutus rantai penularan, menyembuhkan penderita, dan mencegah kekebalan terhadap obat $\mathrm{TB}$, setelah pelatihan meningkat menjadi $78,9 \%$. Pencegahan penyakit TB dapat dilakukan dengan pemberian immunisasi BCG pada bayi yang baru lahir. Sebagian besar kader tidak mengetahui bahwa penyakit TB dapat dicegah dengan BCG, bahkan kader beranggapan bahwa penyakit TB dicegah dengan obat (Tabel 5).

Sebelum pelatihan,hanya sekitar $40 \%$ kader yang mengetahui PMO yang merupakan singkatan dari Pengawas Menelan Obat dan setelah pelatihan meningkat secara signifikan $(98,9 \%)$. Hal yang sama, pengetahuan kader tentang fungsi PMO secara benar sebelum pelatihan adalah $37,8 \%$ kader dan meningkat secara signifikan 
Tabel 3. Distribusi Kader Berdasarkan Pengetahuan Penyebab TB Sebelum dan Setelah Pelatihan

\begin{tabular}{|c|c|c|c|c|c|c|c|c|c|}
\hline \multirow{3}{*}{ Variabel } & \multirow{3}{*}{ Kategori } & \multicolumn{4}{|c|}{ Sebelum Pelatihan } & \multicolumn{4}{|c|}{ Setelah Pelatihan } \\
\hline & & \multicolumn{2}{|c|}{ Ya } & \multicolumn{2}{|c|}{ Tidak } & \multicolumn{2}{|c|}{ Ya } & \multicolumn{2}{|c|}{ Tidak } \\
\hline & & $\mathbf{n}$ & $\%$ & $\mathbf{n}$ & $\%$ & $\mathbf{n}$ & $\%$ & $\mathbf{n}$ & $\%$ \\
\hline \multirow{5}{*}{ Penyebab TB } & Merokok & 18 & 20 & 72 & 80 & 4 & 4,4 & 86 & 95,6 \\
\hline & Angin malam & 10 & 11,1 & 80 & 88,9 & 1 & 1,1 & 89 & 98,6 \\
\hline & Bakteri (kuman) & 55 & 61,1 & 35 & 38,9 & 81 & 90 & 9 & 10 \\
\hline & Virus & 20 & 22,2 & 70 & 77,8 & 9 & 10 & 81 & 90 \\
\hline & Lain-lain & 1 & 1,1 & 89 & 98,8 & 3 & 3,3 & 87 & 96,7 \\
\hline \multirow[t]{6}{*}{ Penularan TB } & Melalui makanan & 23 & 25,6 & 67 & 74,4 & 12 & 13,3 & 78 & 86,9 \\
\hline & Melalui air & 3 & 3,3 & 87 & 96,7 & 1 & 1,1 & 89 & 98,9 \\
\hline & Percikan darah & 5 & 5,6 & 85 & 94,4 & 42 & 46,7 & 48 & 53,3 \\
\hline & Asap rokok & 18 & 20 & 72 & 80 & 6 & 6,7 & 84 & 93,3 \\
\hline & Tidak tahu & 2 & 2,2 & 88 & 97,8 & 0 & 0 & 90 & 100 \\
\hline & Lain-lain & 26 & 28,9 & 64 & 71,1 & 24 & 26,7 & 66 & 73,3 \\
\hline
\end{tabular}

Tabel 4. Distribusi Pengetahuan Kader Tentang Gejala Utama dan Pemeriksaan Penderita TB Paru Sebelum dan Setelah Pelatihan

\begin{tabular}{|c|c|c|c|c|c|c|c|c|c|}
\hline \multirow{3}{*}{ Variabel } & \multirow{3}{*}{ Kategori } & \multicolumn{4}{|c|}{ Sebelum Pelatihan } & \multicolumn{4}{|c|}{ Setelah Pelatihan } \\
\hline & & \multicolumn{2}{|c|}{ Ya } & \multicolumn{2}{|c|}{ Tidak } & \multicolumn{2}{|c|}{ Ya } & \multicolumn{2}{|c|}{ Tidak } \\
\hline & & $\mathbf{n}$ & $\%$ & $\mathbf{n}$ & $\%$ & $\mathbf{n}$ & $\%$ & $\mathbf{n}$ & $\%$ \\
\hline \multirow[t]{6}{*}{ Gejala utama TB } & Batuk 2 minggu & 81 & 90 & 9 & 10 & 86 & 95,6 & 4 & 4,4 \\
\hline & Batuk kurang 2 minggu & 3 & 3,3 & 87 & 96,7 & 6 & 6,7 & 84 & 93,3 \\
\hline & Muka pucat & 1 & 1,1 & 89 & 98,9 & 3 & 3,3 & 87 & 96,7 \\
\hline & Badan kurus & 12 & 13,3 & 78 & 86,7 & 10 & 11,1 & 80 & 88,9 \\
\hline & Tidak tahu & 1 & 1,1 & 89 & 98,9 & 0 & 0 & 90 & 100 \\
\hline & Lain-lain & 1 & 1,1 & 89 & 98,9 & 0 & 0 & 90 & 100 \\
\hline \multirow[t]{6}{*}{ Pemeriksaan TB } & Periksa dahak & 58 & 64,4 & 32 & 35,6 & 77 & 85,6 & 13 & 14,4 \\
\hline & Foto paru & 9 & 10 & 81 & 90 & 13 & 14,4 & 77 & 85,6 \\
\hline & Tes tuberkulin & 5 & 5,6 & 85 & 94,4 & 3 & 3,3 & 87 & 96,7 \\
\hline & Minimal 2 pemeriksa & 31 & 34,4 & 59 & 65,6 & 18 & 20 & 72 & 80 \\
\hline & Tidak tahu & 1 & 1,1 & 89 & 98,9 & 0 & 0 & 90 & 100 \\
\hline & Lain- lain & 7 & 7,8 & 83 & 92,2 & 0 & 0 & 90 & 100 \\
\hline
\end{tabular}

setelah pelatihan menjadi 95,6\% (Tabel 6).

\section{Pembahasan}

Semakin dewasa, semakin tinggi tingkat kematangan dan kekuatan seseorang dalam berpikir dan bekerja. Berdasarkan kepercayaan masyarakat, seseorang yang lebih dewasa lebih dipercayai karena pengalaman dan kematangan jiwa. ${ }^{7}$ Usia kader berhubungan dengan penemuan suspek TB paru, usia muda adalah usia produktif yang akan lebih mudah menemukan suspek TB Paru, tetapi kesibukan pekerjaan sering menjadi hambatan. Kelompok muda adalah kelompok usia produktif yang mempunyai pekerjaan lain dan tidak dapat aktif pada kegiatan kader yang sering dilaksanakan pada pagi hari. Pendidikan memengaruhi cara pandang seseorang terhadap diri dan lingkungan serata menuntun manusia untuk berbuat dan mengisi kehidupan. ${ }^{8}$ Pendidikan kader memengaruhi kemampuan penemuan suspek TB paru. Pendidikan yang makin tinggi lebih mudah menerima materi yang diberikan dalam pelatihan penemuan suspek TB paru. Di Kelurahan Mojo tahun 2013, kader yang mengikuti pelatihan penemuan suspek tersebut terbanyak adalah pada kelompok kader yang berpendidikan SMA $(58,9 \%)$ dan yang terendah adalah pada kelompok pendidikan perguruan tinggi $(3,3 \%)$ sehingga kader di kelurahan Mojo berpotensi mudah menemukan suspek TB paru. Menurut Gibson, pendidikan berperan besar dalam produktivitas, semakin berpendidikan tingkat produktivitas pekerja semakin baik. ${ }^{9}$ Pekerjaan profesi seperti guru, petugas medis yang berpendidikan tinggi mempunyai daya cipta yang lebih baik dari pada pekerja yang lebih rendah.

Pada penelitian lain, terjadi peningkatan pengetahuan setelah pelatihan. ${ }^{10}$ Penyuluhan atau pelatihan merupakan bagian pendidikan kesehatan yang tergabung dalam upaya kesehatan yang menitikberatkan upaya peningkatan perilaku sehat. Masyarakat memahami perilaku mereka dan mekanisme pengaruh perilaku pada pengobatan penyakit dan membantu pemulihan. ${ }^{11}$ Dalam pelaksanaan pendidikan kesehatan terdapat proses bela- 
Wahyuni \& Artanti, Pelatihan Kader Kesehatan untuk Penemuan Penderita Suspek TB

Tabel 5. Pengetahuan Kader Tentang Lama dan Tujuan Pengobatan Tuberkulosis Sebelum dan Setelah Pelatihan

\begin{tabular}{|c|c|c|c|c|c|c|c|c|c|}
\hline \multirow{3}{*}{ Variabel } & \multirow{3}{*}{ Kategori } & \multicolumn{4}{|c|}{ Sebelum Pelatihan } & \multicolumn{4}{|c|}{ Setelah Pelatihan } \\
\hline & & \multicolumn{2}{|c|}{ Ya } & \multicolumn{2}{|c|}{ Tidak } & \multicolumn{2}{|c|}{ Ya } & \multicolumn{2}{|c|}{ Tidak } \\
\hline & & $\mathbf{n}$ & $\%$ & $\mathbf{n}$ & $\%$ & $\mathbf{n}$ & $\%$ & $\mathbf{n}$ & $\%$ \\
\hline \multirow[t]{4}{*}{ Lama pengobatan TB } & Lama 6 bulan & 79 & 87,8 & 11 & 12,2 & 85 & 94,4 & 5 & 5,6 \\
\hline & $<6$ bulan & 8 & 8,9 & 82 & 91,1 & 5 & 5,6 & 85 & 94,4 \\
\hline & Tidak tahu & 1 & 1,1 & 89 & 98,9 & 0 & 0 & 90 & 100 \\
\hline & Lain-lain & 3 & 3,3 & 87 & 96,7 & 0 & 0 & 90 & 100 \\
\hline \multirow[t]{4}{*}{ Tujuan pengobatan } & Mutus rantai & 23 & 25,6 & 67 & 74,4 & 14 & 15,6 & 76 & 84,4 \\
\hline & Sembuhkan pasien & 27 & 30,0 & 63 & 70 & 17 & 18,9 & 73 & 81,1 \\
\hline & Cegah kebal & 6 & 6,7 & 84 & 93,3 & 7 & 7,8 & 83 & 92,2 \\
\hline & Semua benar & 52 & 57,8 & 38 & 42,2 & 71 & 78,9 & 19 & 21,1 \\
\hline \multirow[t]{3}{*}{ Pencegahan TB } & Imunisasi & 26 & 28,9 & 64 & 71,1 & 54 & 60 & 36 & 40 \\
\hline & Obat & 27 & 30 & 63 & 70 & 30 & 33,3 & 60 & 66,7 \\
\hline & Lain2 & 6 & 6,7 & 84 & 93,3 & 12 & 13,3 & 78 & 86,7 \\
\hline
\end{tabular}

Tabel 6. Distribusi Pengetahuan Kader tentang Pengawas Minum Obat Sebelum dan Setelah Pelatihan

\begin{tabular}{lcccccccccc}
\hline & \multicolumn{3}{c}{ Sebelum Pelatihan } & \multicolumn{3}{c}{ Setelah Pelatihan } \\
\cline { 2 - 11 } Kategori & \multicolumn{2}{c}{ Ya } & & \multicolumn{2}{c}{ Tidak } & & Ya & & Tidak \\
\cline { 2 - 11 } & & $\mathbf{n}$ & $\%$ & $\mathbf{n}$ & $\%$ & $\mathbf{n}$ & $\%$ & $\mathbf{n}$ & $\%$ \\
\hline Mengetahui tentang PMO & 36 & 40 & 54 & 60 & 89 & 98,9 & 1 & 1,1 \\
Kepanjangan singkatan PMO & 35 & 38,9 & 1 & 1,1 & 87 & 96,7 & 2 & 2,2 \\
Mengetahui fungsi PMO & 34 & 37,8 & 56 & 62,2 & 86 & 95,6 & 4 & 4,4 \\
Benar tentang fungsi PMO & 32 & 35,6 & 2 & 2,2 & 79 & 87,8 & 6 & 6,7 \\
\hline
\end{tabular}

jar yang merupakan pengalaman, berbuat, bereaksi, dan melampaui. Hasil belajar adalah pola-pola perbuatan, nilai-nilai, pengertian-pengertian, sikap-sikap, apresiasi, abilitas, dan keterampilan. Belajar dapat dilakukan dengan memberikan pengajaran dan pelatihan kepada sasaran. ${ }^{12}$ Pengetahuan kader tentang TB paru perlu dijabarkan mulai dari pengertian tentang TB paru, gejala TB paru, penularan, pencegahan, dan cara pengobatan TB paru. Dengan demikian, kita mengetahui pokok permasalah dan dapat jadi masukan ketika melakukan intervensi pada kader.

Pengetahuan adalah hasil dari tahu yang terjadi setelah seseorang melakukan penginderaan terhadap suatu objek tertentu. Penginderaan terjadi melalui panca indera manusia, meliputi indera penglihatan, penciuman, rasa, dan raba. Sebagian besar pengetahuan manusia diperoleh melalui mata dan telinga. ${ }^{5}$ Pengetahuan seseorang tentang suatu objek mengandung dua aspek meliputi aspek positif dan aspek negatif. Kedua aspek tersebut menentukan sikap seseorang terhadap suatu objek tertentu, semakin banyak aspek positif suatu objek diketahui makin positif sikap terhadap objek tersebut.

Sumber penularan penyakit adalah penderita TB dengan hasil pemeriksaan menunjukan adanya basil tahan asam (BTA) dalam dahak. Ketika batuk atau bersin, penderita menyebarkan kuman ke udara dalam bentuk droplet mengandung kuman yang dapat bertahan di udara pa- da suhu kamar selama beberapa jam. Orang dapat terinfeksi jika droplet tersebut terhirup ke dalam saluran pernapasan. Penyakit TB dapat ditularkan melalui droplet nuclei yang mengontaminasi udara, makanan, dan minuman. Droplet nuclei dikeluarkan pada saat penderita TB batuk berdahak sehingga percikan batuk dan darah tersebut dapat menularkan TB. ${ }^{13}$

Diagnosis TB paru pada orang dewasa ditegakkan dengan penemuan BTA kuman TB. Pada program TB nasional, penemuan BTA melalui pemeriksaan dahak mikroskopis merupakan diagnosis utama. Pemeriksaan lain seperti foto toraks, biakan, dan uji tuberkulin dapat digunakan sebagai penunjang diagnosis sepanjang sesuai dengan indikasi. ${ }^{1}$ Pemeriksaan dahak dilakukan dengan mengumpulkan tiga spesimen dahak yang dikumpulkan dalam dua hari kunjungan berurutan berupa SewaktuPagi-Sewaktu (SPS), uji tuberkulin juga merupakan alat diagnosis TB yang telah dikenal sangat lama, tetapi hingga kini masih mempunyai nilai diagnostik yang tinggi. Secara klinis, nilai tes tuberkulin terbatas, hasil test positif tidak selalu diikuti dengan penyakit, demikian juga dengan hasil tes negatif tidak selalu bukan TB. Ada infeksi primer digambarkan dengan nodul terklasifikasi pada bagian perifer paru dengan klasifikasi limfe nodus hilus. Aktivitas kuman TB tidak dapat hanya ditegakkan hanya dengan satu kali pemeriksaan rontgen dada, tapi harus dilakukan secara serial. Tidak hanya melihat kondisi penyakit dalam proses progesi atau regresi.

\section{Kesimpulan}

Ibu rumah tangga yang menjadi kader kesehatan ratarata berumur 48 tahun dengan pendidikan terbanyak SMA $(31,1 \%)$. Terjadi peningkatan pengetahuan yang signifikan setelah pelatihan dibandingkan dengan sebelum pelatihan.

\section{Saran}

Perlu dilakukan implementasi untuk melihat kemam- 
puan kader menerapkan pengetahuan yang diperoleh untuk menemukan suspek penderita TB di lingkungan mereka. Dalam penerapan tersebut perlu dilakukan pendampingan dan pemantauan dalam proses penemuan suspek TB oleh kader.

\section{Daftar Pustaka}

1. Departemen Kesehatan Republik Indonesia. Pedoman nasional penanggulangan tuberculosis. Edisi ke-2. Jakarta: Departemen Kesehatan Republik Indonesia; 2007.

2. Departemen Kesehatan Republik Indonesia. Pedoman nasional penanggulangan tuberculosis. Edisi ke-2 Jakarta: Departemen Kesehatan Republik Indonesia; 2011

3. Direktorat Jenderal Pengendalian Penyakit dan Penyehatan Lingkungan. Laporan situasi terkini perkembangan TB di Indonesia Januari-Juni 2011. Jakarta: Ditjen PP\&PL Kementerian Kesehatan; 2011.

4. Dinas Kesehatan Kota Surabaya. Profil kesehatan kota Surabaya tahun 2011. Surabaya: Dinkes Kota Surabaya; 2011.

5. Notoatmodjo S. Konsep Perilaku Kesehatan. Promosi Kesehatan, Teori dan Aplikasi. Jakarta: PT Rineka Cipta; 2005.
6. Leida I, Khuzaimah A, Massi MN, Muchlis MA, Sukri, Wahyuni CU. Efek promosi kesehatan yang dilakukan oleh kelompok masyarakat informal (KMI) dalam mendeteksi suspek TB di Kabupaten Gowa [manuskrip tidak terpublikasi]. Jakarta: Kementrian Kesehatan; 2011.

7. Nur Salam. Proses dan dokumentasi keperawatan; konsep dan praktek. Jakarta: Salemba Medika; 2001.

8. Nursalam SP. Metodologi riset keperawatan. Jakarta: CV Sugeng Seto; 2001.

9. Gibson JL, Ivancevich JM, Donnelly JH. Organisasi dan manajemen perilaku, struktur, proses. Djarkasih, penerjemah. Jakarta: Erlangga; 1987.

10. Rahayuningsih, Trisnawati AG, Betty F. Pelatihan peningkatan kemampuan kader dalam penanganan tuberkulosis di Wilayah Kerja Puskesmas Gemolong Sragen. WARTA. 2008; 11 (2): 150-8.

11. Organisasi Kesehatan Sedunia. Pendidikan kesehatan: pedoman pelayanan kesehatan dasar. Bandung-Denpasar: Institut Teknologi Bandung- Universitas Udayana; 2000.

12. Hamalik O. Proses belajar mengajar. Jakarta: Bumi Aksara; 2003.

13. Saroso S. Kumpulan abstrak buletin kesehatan 2008-2009. Jakarta: Perhimpunan Dokter Paru Indonesia; 2009. 